\title{
A randomized trial of immunotherapy in combination with chemotherapy for gastric cancer with peritonitis carcinomatosis.
}

\section{ORIGINAL ARTICLE Annals of Cancer Research and Therapy}

\author{
Toshio Mitomi*1), Hisahiko Motohashi*2), Shuuji Tsuchiya*3), Yuuji Maruyama*4), Kaiho Suzuki ${ }^{* 51}$ \\ Yoshiki Hiki ${ }^{* 6}$, Akihiko Matsumoto ${ }^{* 7}$, Tatsurou Yamakawa ${ }^{* 81}$, Minoru Sugita ${ }^{* 9}$, Kyoji Ogoshi ${ }^{* 1)}$ \\ and The Kanagawa cooperative study group for gastric cancer with peritonitis carcinomatosis
}

\begin{abstract}
We evaluated the effect of immunotherapy using OK-432 in 67 gastric cancer patients with peritonitis carcinomatosis and investigated markers predicting the response to immunotherapy. All patients were followed up until death. The study enrolled 67 patients with biopsy-proved adenocarcinoma of the stomach associated with peritonitis carcinomatosis, of whom 56 underwent operation and 29 underwent gastrectomy. Seven were inoperative and 4 had recurrence with ascites due to peritonitis carcinomatosis. They were randomly assigned to receive chemotherapy with or without a streptococcal biological response modifier OK-432.

Overall survival was not improved by OK-432. However, among the patients with a negative SUPS skin reaction before treatment, those who received OK- 432 had a significantly better outcome than those without OK-432. Cox multivariate regression analysis indicated that postoperative therapy with or without OK-432 was a significant prognostic factor for patients receiving chemotherapy and immunochemotherapy who had a positive and negative SU-PS skin reaction, respectively.

These results indicate that the pretreatment SUPS skin reaction is a possible predictor of the effectiveness of immunotherapy using OK-432.

Ann Cancer Res Ther 3 (1) : 35 39, 1994 / Received 1 Mar 1994, Accepted 22 Mar 1994
\end{abstract} Key words:gastric cancer with peritonitis carcinomatosis, OK-432 SUPS skin reaction

Peritonitis cacinomatosis due to advanced gastric cancer is associated with the worst prognosis along with hepatic metastasis, and many oncological and surgical methods have been tried to improve survival. The effectiveness of immunotherapy has been reported for gastric $^{1,2)}$ and esophageal ${ }^{3)}$ cancer when used in combination with chemotherapy in Japan and as well as for colon cancer in Japan ${ }^{4)}$ and the US ${ }^{5)}$. Mitomycin C (MMC), bleomycin (BLM), fluoropyrimidines, PSK, OK-432, and levamisole were used as the chemotherapeutic or immunomodulating ageents in these trials.

Torisu et al. reported the resolution of massive ascites induced by peritonitis carcinomatosis after OK-432 was given intraperitoneally, suggesting that this agent may have a beneficial effect on such patients ${ }^{6}$.

OK-432 is a biological response modifier prepared from a low-virulence SU strain of Streptococcus pyogenes (gropu A) of human origin. It has been shown to exert an antitumor effect and to potentiate the cytotoxic

\footnotetext{
*1) Second Department of Surgery, Tokai University

*2) Department of Surgery, Kanagawa Cancer Center Hospital

*3) Second Department of Surgery, Yokohama City University

-4) Department of Ist. Surgery, St Marianna University

*5) Department of Surgery, Fujigaoka Hospital, Showa University

*6) Department of Surgery, Kitasato University

*7) First Department of Surgery, Yokohama City University

*8) Department of Surgery, Teikyo University

*9) Department of Public Health, Tokai University, Kanagawa

Correspondence to : Kyoji Ogoshi, MD, Department of Surgery, School of

Medicine, Tokai University, Bohseidai, Isehara, Kanagawa 259-11, Japan
}

activity of various effecter cells as well as inducing various cytokines ${ }^{7,8)}$.

In Japanese clinical trials, a beneficial effect of OK-432 on gastric cancer was obtained in combination with chemotherapy, but most of the studies performed were not randomized trials. There are many tumor markers available for monitoring disease progression and the effectiveness of treatment, but they are unable to predict the response to therapy ${ }^{9}$

The present study investigated the efficacy of immunotherapy using OK-432 for gastric cancer associated with peritonitis carcinomatosis, and evaluated the clinical usefulness of the following markers : $\alpha 1$ antichymotrypsin $(\mathrm{ACT})^{10)}$, sialic acid $(\mathrm{SA})^{11)}$, immunosuppressive acidic protein (IAP) ${ }^{12)}$, and acid soluble glycoproteins $(\mathrm{ASP})^{13)}$ : These are acute phase reactants (APRs) and have a immunosuppressive effect. In addition, the value of skin tests with purified protein derivarate (PPD) and a polysaccharide extracted from the Su strain of Streptococcus pyogenes (SUPS) was assessed.

Materials and methods

A randomized controlled study of gastric cancer was undertaken from October 1986 to December 1988 at 16 institutions in Kanagawa Prefectrue, Japan. The 67 
Table 1 Variables used in the Cox regression model,

\begin{tabular}{lc}
\hline Prognostic factor & Value/score \\
\hline Sex & (1) male, (2) female \\
Ascites & (1) $(-),(2)(+)$ \\
Histopathological & (1) well, (2) undifferentiated \\
types & (1) without OK-432, (2) with OK-432 \\
Therapy &
\end{tabular} $\begin{aligned} & \text { well : papillary, well differentiated or moderately differentiated } \\
& \text { adenocarcinoma. } \\
& \text { undifferentiated : mucinous carcinoma, pooly differentiated } \\
& \text { adenocarcinoma and signet ring cell carcinoma. }\end{aligned}$

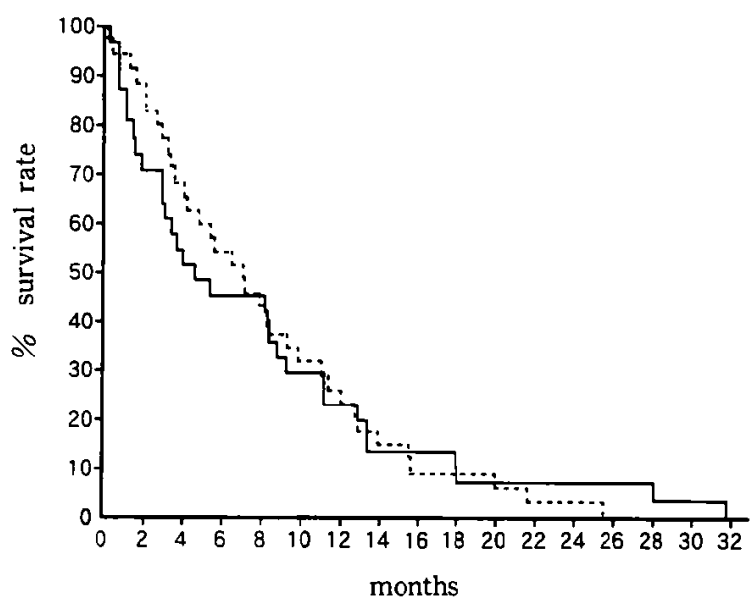

Fig.1 Survival of patients with( - ) and without( $(\cdots \cdots)$ OK-432 therapy

patients eligible for enrollment in the trial had biopsyproven adenocarcinoma of the stomach associated with peritonitis carcinomatosis. All the patients gave informed consent to the study. Patients who had a history of other malignancies or double cancer were excluded. Patients with recurrence who had received chemotherapy within 4 weeks were also excluded. Normal serum electrolytes, blood urea nitrogen, and serum creatinine levels, and no cardiac failure were also required. In addition, a white blood cell count of at least $2,000 / \mathrm{mm}^{3}$ and a platelet count of at least $50,000 \mathrm{~mm}^{3}$ were required prior to starting treatment

Patients were stratified according to sex, resection or non-resection and the nonoperation or recurrence, and then were randomized to receive a treatment regimen with or without OK-432 (Picibanil, Chugai Pharmaceutical Co., Ltd., Tokyo, Japan).

In the immunochemotherapy + surgery group, patients were intraoperatively underwrent intraperitonel administration of OK-432 at a dose of $10 \mathrm{KE}$ ( $1 \mathrm{KE}=0.1 \mathrm{mg}$ of dried streptococcal cells)with concomitant intravenous injection of mitomycin (MMC) (Kyowa Hakko Co., Ltd., Tokyo, Japan) at a dose of $0.4 \mathrm{mg} / \mathrm{Kg}$. MMC was

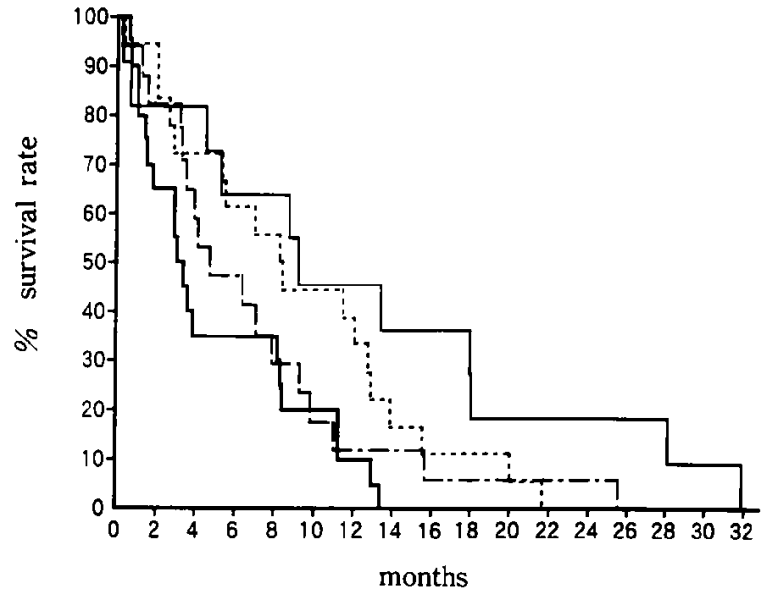

Fig.2 Survival of patients with and without gastrectomy according to therapy

Gastrectomy group : patients with(-)and without (…..) OK-432. Nongastrectomy group : patients with(-)and without(---)OK-432

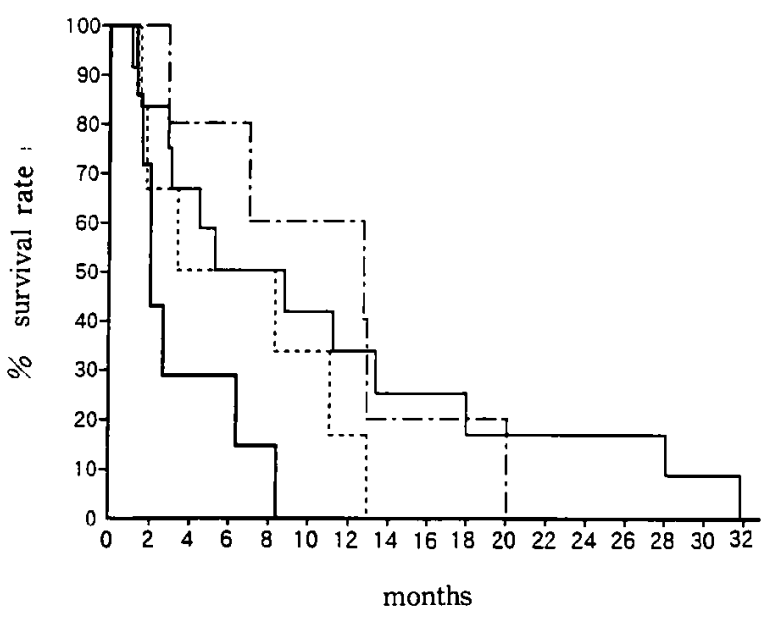

Fig.3 Survival of 32 patients undergoing SUPS skin testing according to the treatment Positive SUPS skin reaction group : patients with $(\cdots \cdots)$ and without $(---)$ OK-432. Negative SUPS skin reaction group : patients with $(--)$ and without(-)OK-432

also given on postoperative day 1 . This was followed by oral administration of 1-hexylcarbamoyl-5-fluorouracil (HCFU) (Mitsui Pharmaceutical Co., Ltd., Tokyo, Japan) $(400 \mathrm{mg} /$ day) from day 14 after surgery. The starting dose of OK-400 was $1 \mathrm{KE}$ on postoperative day 1. The drug was injected intradermally and the dose was increased at 2-day intervals to 3 and $5 \mathrm{KE}$, after which 5 $\mathrm{KE}$ was given at 2-day intervals throughout the hospital stay. After discharge, maintenance therapy was continued with $5 \mathrm{KE}$ once a week for a period of at least 3 months unless there was progression of the cancer. In the patients without surgery, treatment protocol was the 
Table 2 Multivariate analysis of factors related to survival in 32 patients with a positive or negative SUPS skin reaction

\begin{tabular}{l|cc|cc|rc}
\hline & \multicolumn{2}{|c|}{ SUPS skin test $(+)$} & \multicolumn{2}{c}{ SUPS skin test $(-)$} & \multicolumn{2}{c}{ Total } \\
\hline & \multicolumn{2}{|c|}{ Coefficient $p$ value } & \multicolumn{2}{c}{ Coefficient p value } & \multicolumn{2}{c}{ Coefficient p value } \\
\hline Sex & -1.610 & 0.098 & -1.731 & 0.016 & -0.506 & NS \\
Ascites & 2.290 & 0.020 & 0.716 & NS & 0.295 & NS \\
Histology & -1.225 & NS & -0.054 & NS & -0.464 & NS \\
Therapy & 1.933 & 0.049 & -2.191 & 0.005 & -0.841 & NS \\
\hline NS : $p>0.1$
\end{tabular}

same except for no operation.

Among the 67 patients enrolled, 6 (8.9\%) patients died within 30 days of staring treatment because of tumor progression, and $2(3.0 \%)$ were lost to follow up.

Thirty-five patients were assigned to the chemotherapy group ( 18 received gastrectomy, 12 were not resected, and 5 had recurrent or inoperable disease) and 32 to the immunochemotherapy group (11 received gastrectomy, 14 were not resected, and 7 had recurrent or inoperable disease). Four patients died within 30 days and one was lost to follow up in the immunochemotherapy group, while the respective numbers were 2 and 1 in the chemotherapy group.

Pretreatment blood samples were collected from each hospital and taken to Mitsubishi Yuka BCL Co., Ltd., where the serum levels of APRs were examined. Fortyone patients had the serum levels of APRs determined. The serum ACT levels was determined by the single radial immunodiffusion method using antisera and standards supplied by the Department of Molecular Life Science (Tokai University, Japan). The serum SA level was determined using a modified resorcinol reagent kit (Kyokuto sialic acid test, Kyokuto Pharmaceutical Co., Ltd., Tokyo, Japan). The level of IAP, which is closely related to $\alpha-1$-acid glycoprotein, was determined using a commercial kit (IP plate, Sanko Junyaku Co., Ltd., Tokyo, Japan). The level of ASP, a perchloric acid soluble glycoprotein, was determined with an ASPROGP kit (Otsuka Assay Laboratories Co., Ltd., Tokushima, Japan). ASP is almost identical to the seromucoid determined by Winzler's method.

In this study, the reference value for ACT, SA, IAP, and ASP were defined as $280 \mu \mathrm{g} / \mathrm{ml}, 85.3 \mu \mathrm{g} / \mathrm{dl}, 558 \mu \mathrm{g} /$ $\mathrm{ml}$ and $148 \mathrm{mg} / \mathrm{ml}$, respectively ${ }^{13 \sim 16}$.

Among the 67 patients, 32 were tested for their skin reaction to PPD and SUPS. SUPS (Chugai Pharmaceutical Co., Ltd.), or PPD was injected intradermally at dose of $20 \mathrm{mg} / 0.1 \mathrm{ml}$ and $0.05 \mathrm{mg} / 0.1 \mathrm{ml}$, respectively. The erythematous skin reaction was measured after 48 hours and 24 hours, respectively, with erythema greater than 10 $\mathrm{mm}$ wide taken as positive.

Survival was assessed from the day of operation or initiation of treatment until death. Sixty-five patients were followed up until death. Survival curves were produced using the Kaplan-Meier method and differences in survival were assessed by the log-rank test.

In 32 patients who were assessed for the SUPS skin reaction, multivariate analysis utilizing Cox's model was performed with four variables : sex, histological grade, ascites, and treatment with or without OK-432. The variables employed in the Cox regression model are shown in Table 1.

\section{Results}

The patients ranged from 33 to 78 years old (median : 58 years) and $59.7 \%$ were men.

It was difficult to determine the toxicity related to treatment, because of the death of some patients within 30 days due to tumor progression. In the chemotherapy group, nausea was noted in 2 patients. Nausea and high fever were noted in one patient from the immunochemotherapy group. These patients could not continue therapy until death.

The 2-year survival rates of the patients with and without OK-432 therapy were $6.5 \%$ and $2.9 \%$, respectively (Fig.1). There was no significant difference in survival between the immunochemotherapy group and the chemotherapy group. For patients with or without gastrectomy, there were no significant differences in survival between the chemotherapy and immunochemotherapy groups (Fig.2). There was also no significant difference in survival between the patients with abnormal or normal APR levels and those with or without a normal PPD skin reaction.

Among the 19 patients with a negative skin reaction to SUPS, the 2-year survival rate for those with or without OK-432 therapy was $16.7 \%$ and $0.0 \%$, respectively. There was a significant difference in survival between these groups (log-rank test, $\mathrm{p}<0.05$ ). On the other hand, among the 13 patients with a positive reaction to SUPS, there was no significant difference in survival between those with or without OK-432 therapy (Fig.3).

Tables 2 shows the results of multivariate analysis of 
the factors related to survival among the patients receiving SUPS skin testing. In the whole group of patients, there were no factors with a significant influence on survival. However, ascites and postoperative adjuvant therapy were significantly related to survival in the patients with a positive SUPS skin reaction. On the other hand, in the patients with a negative skin reaction, postoperative adjuvant therapy and sex were significantly related to survival. Postoperative chemotherapy was more effective in the patients with a positive reaction to SUPS and postoperative chemotherapy+OK-432 was more effective in those with a negative reaction to SUPS.

\section{Discussion}

Several clinical studies of gastric cancer have demonstrated the clinical effectiveness of immunotherapy using OK-4322.14), but, the value of OK-432 for patients with malignant ascites was not clear. A randomized study of patients with peritonitis carcinomatosis due to gastric cancer by the Japanese Foundation for Multidisciplinary Treatment of Cancer ${ }^{15}$ found no difference in survival between patients receiving chemotherapy with or without OK-432, and the same result was noted in our trial.

When we started this trial in 1986, combination therapy with $\mathrm{OK}-432$ and $\mathrm{HCFU}$ had been reported to produce better results for peritonitis carcinomatosis, because the concentration of HCFU is high in ascitic fluid ${ }^{16)}$ and because OK-432 directly kills cancer cell in ascites $^{17,18)}$.

Individual patients should receive rationally designed adjuvant therapy, but this necessitates the evaluation of parameters that can predict the treatment response and prognosis.

Many tumor-associated markers may be useful in assessing the effectiveness of cancer therapy. We have reported that both gastric and esophageal cancer patients with abnormal SA levels showed a better prognosis than those with normal SA levels if they received immunotherapy using protein-bound polysaccharide K (PSK), an immunopotentiator prepared from Coriolus vesicolor (Fr.) Quel, in combination with chemotherapy ${ }^{19,20}$. We also found that gastric cancer patients with abnormal levels of immunosuppressive acidic protein (IAP) who underwent total or proximal gastrectomy plus splenectomy responded well to postoperative immunotherapy ${ }^{21)}$. We suggest that preoperative serum APR values are also correlated with a better response to PSK in both esophageal and gastric cancer. On the other hand, patients with abnormal SA levels did not show a good response to OK-432 in the present study, but those with a negative SUPS skin test showed a good response to OK-432. From the results of the present study and the above mentioned reports, it appears that there may be different predictors for the immunopotentiators PSK and OK-432.

It has been reported that patients with a positive SUPS reaction have a good prognosis and that those who change from a negative to a positive SUPS reaction have a good response to OK-432 treatment $^{22,23)}$. However, the relationship between the preoperative SUPS reaction and the effectiveness of OK-432 has been unclear. A negative SUPS skin reaction means that the patient have not had streptococcal infection. The present study suggests that the effectiveness of OK-432 depends on the lack of streptococcal infection before treatment.

We conclude that preoperative assessment of the SUPS skin reaction can help clinicians to decide on OK-432 treatment for gastric cancer with peritonitis carcinomatosis. However, as this trial employed a small number of patients, further evaluation of the association between the SUPS skin reaction and OK-432 should be undertaken in the future. Neverhteless, the studies performed to date have led to the conclusion that prolongation of survival is observed when immunochemotherapy using OK-432 is given to patients with a negative SUPS reaction and chemotherapy is given to those with a positive SUPS reaction.

\section{References}

1) Hattori T, Inokuchi K, Taguchi T, Abe O. : Postoperative adjuvant chemotherapy for gastric cancer, the second report. Analysis of data on 2873 patients followed for five years. Jpn J Surg, 16:175-180, 1986, (in Japanese).

2) Kyoto Research Group for Digestive Organ Surgery : A comprehensive multiinstitutional study on postoperative adjuvant immunotherapy with oral streptococcal preparation OK-4.32 for patients after gastric cancer surgery. Ann Surg. $216: 44-54,1992$.

3) Ogoshi K. Satou H, Isono Kaichi, Mitomi T, Endoh M, Sugita M. : Immunotherapy for esophageal cancer ; a randomized trial in combination with radiotherapy and radiochmotherapy. Am J Clin Oncol, $17: 1994$ (in press).

4) Mitomi T, Tsuchiya S, lijima N, Aso K, Suzuki K, Nishiyama K, Amana T, Takahashi T, Murayama N, Oka H, Oya K. Noto T, Ogawa N. : Randomized, controlled study on adjuvant immunochemotherapy with PSK in curatively resected colorectal cancer. Dis Colon Rectum, 35: 123-130, 1992.

5) Moertel CG, Fleming TR, Macdonald JS. Haller DG, Laurie JA, Goodman PJ, Ungerleider JS, Emerson WA, Tormey DC, Glick JH, Veeder MH, Mailliard JA. : Levamisole and fluorouracil for adjuvant therapy of resected colon carcinoma. $\mathrm{N}$ Eng J Med $322:$ 352-358, 1990.

6) Torisu M, Katano M, Kimura $Y$, Itoh $H$, Takesue $M$. : New approach to management of malignant ascites with a streptoccocal preparation, OK-432I. : Improvement of host immunity and prolongation of survival. Surgery, $93: 357-364,1983$.

7) Uchida A, Mickshce $M$. : Intrapleural administration of $O K$ 432 in cancer patients. Activation of NK cells and reduction of suppressor cells. Int J Cancer, 31: 1 -5, 1983.

8) Yang KD, Stone RM, Lee CS, Chao TY, Cheng, SN, Shaio 
MF. : Effect of picibanil (OK432) on neutrophil-mediated antitumor activity : implication of monocyte-derived neutrophil-activating factors. Cancer Immunol Immunother, $35: 277-282,1992$.

9) Cohn SL, Lincoln ST, Rosen ST. : Present status of serum tumor markers in diagnosis, prognosis, and evaluation of therapy. Cancer Invest, $4: 305-327,1986$.

10) Tsuda M. , Masuyama M. and Katunuma T. : Inhibition of human DNA polymerase $\alpha$ by $\alpha$ l-antichymotrypsin. Cancer Research, $46: 6139-6142,1986$.

11) Gemba T, Kagwaguchi A, Ueda $H$, Sakata M. A method for simple and rapid determination of sialic acid in serum and its clinical significance with special reference to patients with various malignant tumors. J Transportation Med, 34 : 309 . 315, 1980, (in Japanese).

12) Tamura $K$, Shibata $Y$, Matuda $Y$, Ishida N. : Isolation and characterization of an immunosuppressive acidic protein from ascitic fluid of cancer patients. Cancer Research, $41: 3244-$ $3252,1981$.

13) Nakajima K, Kodaira T, Ichioka $Y$, Nitta $H$, Nakagawa $H$, Yamamoto S, Chikakiy H, Ohtani H. : A new method of serum mucoprotein (acid soluble glycoproteins : ASP) assay using Coomassie Brilliant Blue G-250. Clin Chemo Ther, $11: 214-221,1982$, (in Japanese).

14) Arinaga $S$, Karimine $N$, Takamuku $K$, Nanbara $S$, Inoue $H$, Abe $R$, Watanabe D, Matsuoka $H$, Ueo $H$, Akiyoshi $T$. : A trial of adjuvant chemoimmunotherapy with mitomycin $\mathrm{C}$ and OK-432 for stage III gastric carcinoma. J Surg Oncol, 50 187-189, 1992

15) Sugimachi $K$, Maehara $Y$, Akazawa $K$, Kondo $Y$, Kunii $Y$, Kitamura M, Yamaoka H. Takahashi Y, Kito T, Katou M, Furukawa H. Takashima S : Postoperative chemotherapy including intraperitoneal and intradermal administration of the streptococcal preparation $\mathrm{OK}-432$ for patients with gastric cancer and peritoneal dissemination : a prospective randomized study. Cancer Chemother Pharmacol, 33 : 366-370, 1994

16) HCFU clinical study group. : Absorption and excretion of a new oral antitumordrug, 1-hexylcarbamoyl-5-fluorouracil (HCFU), in cancer patients. Jpn J Clin Oncol, 10:83-92, 1980.

17) Katano M, Torisu M. : Neutrophil-mediated tumor cell destruction in cancer ascites. Cancer, $50: 62-68,1982$.

18) Morisaki T, Toriso $M$, : Enhanced adherence activity of OK-432-induced peritoneal neutrophils to tumor cells correlates to their increased expression of $\mathrm{CD} / \mathrm{lb} / \mathrm{CD} / 8$. Clin Immunol Immunopathol, $59: 474-486,1991$.

19) Ogoshi K, Kondoh Y, Tajima T, Mitomi T. : Glycosidically bound sialic acid levels as a predictive marker of postoperative adjuvant therapy in gastric cancer. Cancer Immunol Immunother, $35: 175-80,1992$.
20) Ogoshi K, Satou H, Isono Kaichi, Mitomi T, Endoh M, Sugita M. : Possible predictive markers of immunotherapy in esophageal cancer ; retrospective analysis of a randomized study. Cancer Invest. 1994, (in press).

21) Ogoshi K, Miyazi M, Iwata K, Kondoh Y, Tajima T, Mitomi $\mathrm{T}$. : Splenectomy, immunosuppressive acidic protein and postoperative immunotherapy in gastric cancer patients with total or proximal gastrectomy; a multivariate analysis. Ann Cancer Res Ther, $1: 61-66,1992$.

22) Watanabe $Y$, Yamada $T$, Kobayashi $H$, Sato $H$, Iwa $T$. Clinical significance of SU-polysaccharide skin test as a parameter for immunotherapy with streptococcal preparation, OK-432. Jpn J Cancer Chemother, $8:$ 1076-1083, 1981, (in Japanese).

23) Hanaue $\mathrm{H}$, Nomoto $\mathrm{S}$, Yoshizaki S : Immunological parameters and prognosis in cancer patients treated with immunotherapy. Jpn J Gastroenterl Surg, 16 : 1374-1379, 1983, (in Japanese)

\section{Appendix}

The Kanagawa cooperative study group for gastric cancer with peritonitis carcinomatosis includes the following members : Yasumasa Kondoh, Second Department of Surgery, Tokai University, Isehara ; Motonori Sairenji Department of Surgery, Kanagawa Cancer Center Hospital, Yokohama ; Kiyoshi Nishiyama, Togou Shinji, Second Department of Surgery, Yokohama City University, Yokohama : Shuuhei Suzaki. Hiroshi Suwa, Yokosuka Kyosai Hospital, Yokosuka ; Hiroshi Takemura, Hideki Kikuchi, Takashi Nagashima, Department of 1st. Surgery, St. Marianna University ; Akio Nakayoshi, Kimio Namatame, Tadaaki Ikeda. Department of Surgery, Fujigaoka Hospital, Showa University ; Kanki Mieno, Department of Surgery, Kitasato University ; Katsuaki Kataba. Toyota Yamanaka, Department of 2nd. Surgery, St. Marianna University ; Tomishige Amano, Toshio Imada, First Department of Surgery, Yokohama City University, Yokohama ; Kazuhiro Horikuchi, Kunihiko Masukawa, Ashigarakami Prefectural Hospital ; Hiroshi Takemura, Hidetarou Yokoyama, Saiseikai Yokohamashi-Nambu Hospital ; Tishiki Takahashi, Hirohiko Minoura, Yohei Yasogawa, Department of Surgery, Sagamihara National Hospital, Sagamihara ; Hiroyoshi Koizumi, Yoshikazu Fujimoto, Department of Surgery, Hiratsuka Kyosai Hospital, Hiratsuka, Hitoshi Kaneko, Nariko Yoshimura, Department of Surgery, Teikyou University Hospital at Mizonokuchi ; Takao Jyoujima, Hatano Red Cross Hospital, Hatano ; Mitsuhiro Kubota, Hitoshi Hanaue, Department of Surgery, Ooiso Hospital, Tokai University : Kangawa, Japan.

Dr. K. Suzuki and Dr. H. Hanaue are now deceased. 
A clinical study of CEA doubling time in recurrent lung adenocarcinoma

Yutaka Takahashi et al.

CEA高値を呈した肺腺癌再発症例46例を对象に，無治 療時のCEAダブリングタイムを求めるとともに，それに 関わる因子を臨床病理学的諸因子から検討した。

その結果, CEAダブリングタイムは, 13〜168日と広い 範囲に分布し，平均64.8 447.1 (SD) 日，中央値47日であ つた，CEAダブリングタイムを左右する因子の検討で は，性別で差はみられなかったのに対し，年跲では，60 歳以下の19例では15 62日, 平均34.9土15.5日，60歳以上 の27例では13〜168日, 平均80.6士49.1日であり, 両者の あいだに有意差が認められた，組織分化度では，低分化 型腺癌9例で13 58日, 平均27.8土15.8日で, 高分化型腺 癌18例が22 153日, 平均 $72.1 \pm 48.3$ 日, 中分化型腺癌 19 例が23〜168日，平均71.5土50.1日であるのにくらべると， 有意に小さい值であった，さらに，再発部位では，脳の

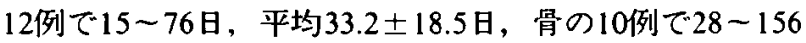

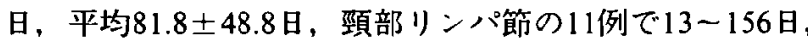
平均74.8 \pm 47.4 日, 肺の10例で $22 \sim 168$ 日, 平均 $94.2 \pm 63$. 8日であり，脳と他の部位で有意の差が認められた。

以上より，肺腺癌のCEAダブリングタイからみた発 育速度に影響する因子は，年数では若い症例，組織分化 度では低い症例で発育速度が速いことが示された。また， 再発部位では，脳が他の部位に比し有意に発育速度が速 い成績が得られたが，これは肺腺癌の再発の中で，脳再 発が最も早い時期に発生する臨床的所見と一致するもの と考えられた。

\section{Locally recurrent gastric adenocarsinoma responsive to} cisplatin, 5-fluouracil and leucovorin p31-34 Yasushi Rino et al.

当科では胃癌術後再発に対し, CDDP, SFU, ロイコ ボリンを併用したFLP療法を施行している，CRの症例 を経験したので報告する。

FLP療法 (CDDP, 5FU，ロイコホリン)で病理学的に CRを得た1例を報告する。

症例は68歳, 女性. stage II $\left(\mathrm{N}_{1} \mathrm{~S}_{1} \mathrm{P}_{0} \mathrm{H}_{0}\right)$ の胃癌で 平成2年3月8日，胃全摘，ROUX-Y再建を施行，絶対治癒 切除であった。

術後，5-FU (150mg/day) の経口投与で外来通院して いた. 平成4年5月よりつか之感出現し，6月29日内視鏡検 查にて吻合部小腸側に潰愓形成，吻合部狭管を認めた。 生検にてgroup V, 局所再発の診断を得た。食餌捸取困 難のため8月11日入院, IVH管理し，全身状態改善し，9月 7日，9月30日より FLP療法 (経静脈的投与) を2回施行し た。副作用は一過性の食思不振, 下痢のみであった. FLP 療法後，2回内視鏡的生検施行し, group I, II であった が, 狭窄症状改善せず, 11月13日狭窄部切除術施行。病 理学的検索で切除標本に癌細胞は認められず, CRを得た と考えた。術後再発の徴候はなく，現在，外来通院中。
A randomized trial of immunotherapy in combination with chemotherapy for gastric cancer with peritonitis carcinomatosis

p35 39

Toshio Mitomi et al.

胃癌の癌性腹膜炎患者は, 肝転移患者同様に非常に予 後不良である。鳥巣らは，癌性腹水に対LOK-432を腹䏶 内に投与し，良好な成績を報告している6). 本稿では，癌 性腹膜炎患者に対するOK-432の有用性を検討するため に神奈川県下で行われた比較対照試験の結果を報告する。

[対象と方法] 对象は癌性腹膜炎を有する胃癌患者 である。1986年10月より88年12月までに67例が登録され た. 67例の内6例 $(8.9 \%)$ が治療後30日以内死亡例で, 2例が 消息不明例となった。化学療法は35例（胃切除例18例, 非切除例 12例, 再発, 非手術例5(例), 化学療法+OK-432 療法は32例（胃切除例11例, 非切除例14例, 再発, 非手 術例7例）に施行された。一部の患者には, 術前にACT, シアル酸，IAP，ASP，およびSUPS皮虑皮内反応を測定 した。

[結 果] (1) OK-432投与の有無では生存率に差 を認めなかった (Fig.1).

(2) 胃切除例では，OK-432投与例が予後良好であった が，有意の差は認められなかった（Fig.2)。

(3) SUPS皮虚皮内反応陽性例では，OK-432投与の有 無で差は見られなかったが，SUPS皮虚皮内反応陰性例 では，OK-432投与例が有意に予後良好であった（Fig. 3).

(4) Coxの比例ハザードモデルでの解析では, SUPS皮 虚皮内反応陽性例では化学療法が, SUPS皮虚皮内反応 㓌性例ではOK-432投与が有意な子後因子であった (Table 2).

[考 察 $]$ OK-432には腹水中の癌細胞に対寸る直 接殺細胞効果があること、フッ化ピリミヂン郕の中では， HCFUの腹水中の濃度が高值であるとの理由で16-18), OK-432 と HCFUの併用は, 癌性腹膜炎に有用であると考 えられた. 癌性腹膜炎に対するstrategyとして上記の楽戍 併用がもっともよい組み合わせであると考えられた。 し かし、結果としてはOK-432の効果は認められなかった。 このことは癌集学的治療財団の特定研究8“胃がん腹膜播 腫例に対するOK-432投与の有用性に関する研究” の研究 報告書でも同様であった ${ }^{15}$.

本研究では, 症例数も少なく断定的なことは将来の問 題としても，治療前にSUPS皮虚皮内反応㓌性例ではOK432の有用性が期待でき, 有意義であると考えられた。 